\title{
French science head faces cash crunch...
}

Paris. France's new government, which was formed in May following the election of Jacques Chirac as president, is expected to provide additional support for research on the human genome, ageing and AIDS. But overall funding for science is likely to be reduced as part of the government's drastic cuts in public spending.

The three research topics have been identified as priorities by Alain Juppé, the prime minister, in a letter to François Bayrou, the minister for national education, higher education, research and professional insertion.

Elisabeth Dufourcq, the secretary of state for research, last week described genome research as the

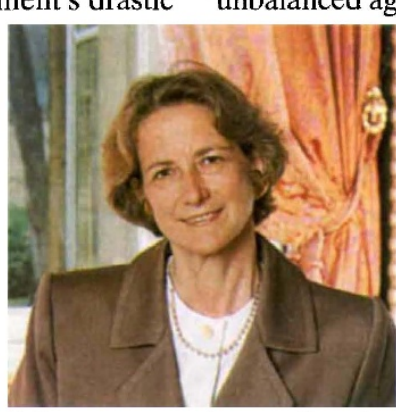

Dufourcq: accepts promises to CNRS have not been met. pendence" in the "essential sector" of life sciences. Her comments follow warnings that French scientists risk being left behind without further substantial government support (see Nature 375, 175; 1995), and she backed proposals that have been made to establish a French megasequencing centre.

Dufourcq was speaking in Paris at her first press conference since her appointment. She has been in her job only a few weeks. But one look at the massive debts accumulated by the Centre National de la Recherche Scientifique (CNRS), and within the ministry's own research funds, has been enough to convince her that the most urgent task she faces is resolving the financial crisis in the research system. "I've become head of this ministry at a time when financial aspects are the priority", she said.

Dufourcq admitted being "very concerned" about the CNRS's financial situation; the agency faces an accumulated debt whose full size is estimated to exceed FF1 billion (US\$200 million), although the exact amount will not be known until an audit of its finances is completed later this month (see Nature 374, 586; 1995).

According to Dufourcq, her immediate priorities are to stabilize the financial situation facing French science, and prevent a recurrence of what she describes as a "dysfunctioning" resulting from institutional, budgetary and management errors.

CNRS's debt has accumulated mainly because payments from the state have failed to keep up with the money promised by the government in the annual budget. Indeed, Dufourcq last week explicitly admitted that the state owes money to CNRS - an admission that the previous government had eschewed, but which has now been "welcomed" by CNRS itself.

Another cause of the agency's financial difficulties, claims Dufourcq, is that having based its recruitment on an overestimate of the anticipated number of staff leaving, it now has about a hundred too many researchers. But with many CNRS researchers due to retire before 2005, a reduction in recruitment is not on the cards, she says, given that it would result in an unbalanced age distribution.

Dufourcq did not say how she plans to tackle CNRS's financial difficulties. "At this time, we can only have a policy of least damage", she says. But according to one CNRS official, the most likely outcome is a rescue programme carried out over several years.

Indeed, there are unlikely to be any miracle solutions to the more general financial problems of French research. Juppé's government has set itself a priority of reducing general public spending in order to reduce the budget deficit and to finance its efforts to reduce unemployment.

Last week, for example, the government cut public spending plans for 1995 in a bid to reduce the anticipated budget deficit from FF371 billion to FF322 billion. The defence ministry, which had been allocated FF99 billion for running costs and FF102 billion for equipment this year, was worst hit, with its budget being cut by FF8.4 billion.

The budgets of other ministries will also be cut, by FF5.2 billion. The government has not yet specified how much of this will fall on science, although Dufourcq says that research has not been "too badly treated, given the difficult budgetary situation". But she says that she intends to control research spending tightly "sector by sector", and to give priority to areas that could lead to "real advances" and not "dreams".

Otherwise, Dufourcq says she will mainly continue the policies initiated by Hubert Curien - who was science minister for much of the $1980 \mathrm{~s}$ under the Socialist governments of François Mitterrand - and continued under Edouard Balladur.

In particular, Dufourcq says she would like to continue the system under which both universities and government-funded research organizations sign five-year contracts with the state fixing their main research objectives and the budgets needed to achieve them. But she emphasized that this policy needs to be pursued in tight collaboration with the heads of the individual research organizations.

Dufourcq's performance in the budget battles ahead is likely to be closely watched. Meanwhile, most observers in Paris say their attitude to her policies is one of "wait and see", giving her the benefit of the doubt, both while she finds her feet in the job, and during the honeymoon traditionally enjoyed by new governments formed after a presidential election.

Declan Butler

\section{and says blood claims are 'simplistic'}

Paris. Elisabeth Dufourcq, France's secretary of state for research, last week expressed reservations about the handling of the contaminated-blood affair one of the first political figures to do so.

In the early 1980 s, haemophiliacs and other transfused patients were infected with HIV through the use of blood products contaminated with the virus. Dufourcq describes the current interpretation of the events as "oversimplified" and "completely reductionist".

Her comments coincided with the first skirmishes in France between supporters and opponents of the interpretation that alleges that officials deliberately ignored evidence that French products were contaminated to avoid importing safer alternatives, and delayed introduction of routine screening of donated blood for HIV until a French diagnostic test was available.

Dufourcq says the affair is not as straightforward as it has been painted. She describes it as a "collective error", in which much of the medical and scientific community must share responsibility for not recognizing the threat of AIDS sooner.
The affair, she adds, reveals the need to educate non-scientists "in the rudiments of statistics needed to exercise intelligent citizenship".

Indeed, writing in Le Monde in 1993 , Dufourcq raised one aspect of the affair that has been neglected - the way in which politicians and scientists estimate risks in deciding to replace one healthcare practice with another.

Both the courts and the media, for example, have argued that health officials should have been aware of the risks of contaminated blood, as a 1983 study of more than 2,000 haemophiliacs found that six showed suspected signs of AIDS. Dufourcq's arguments focus on why such findings are often ignored by scientists.

In particular, she attributes blame to the way that the significance of results is interpreted, claiming that too much emphasis is placed on broad trends, while rare results tend to be dismissed. While this approach usually serves science well, it can have "perverse effects", she argued, and "inhibit the most elementary common sense". D. B. 